\title{
Management of burns during coronavirus disease pandemic: Single center experience and outcomes
}

\author{
Merve Akın, M.D.,' ${ }^{1}$ Ali Emre Akgün, M.D.,1 ${ }^{\circledR}$ Birkan Birben, M.D., ${ }^{1}$ \\ Tezcan Akın, M.D., ${ }^{1}$ 일 Ahmet Çınar Yastı, M.D. ${ }^{2}$ \\ ${ }^{1}$ Department of General Surgery, Ankara City Hospital, Ankara-Turkey \\ ${ }^{2}$ Department of General Surgery, Health Sciences University Faculty of Medicine, İstanbul-Turkey
}

\begin{abstract}
BACKGROUND: Prolonged stays and multiple operations in burn management increase the risk of transmission. We would like to discuss our experience in hospitalized burn patients with Coronavirus disease (covid-19) infection.

METHODS: In-patient burns with confirmed COVID- 19 infection were studied. Age, gender, burned total body surface area (TBSA), number and sort of operations and dressing changes, intensive care unit stay, ward stay, total length of stay, and morbidity and mortality were analyzed. Medical staff observed for infection.

RESULTS: The mean age of the II positive patients was 5 I $( \pm 19.37)$ years and burned TBSA was $34.36 \%( \pm 21.97 \%)$. Six $(54.5 \%)$ patients presented with negative polymerase chain reaction (PCR) tests; however, symptoms and findings revealed the illness. Patients underwent 85 operations including hydrosurgery. Totally, 475 dressing changes were done. Respiratory failure caused three mortalities without sepsis. Age, TBSA, and deep dermal burn percent of the mortalities showed no difference. None of the staff and hospitalized other patients had hospital acquired COVID-19 infection.

CONCLUSION: Healthcare must continue during pandemics. Awareness, proper usage of personal protective equipment, keeping social distance, and strengthened access control to the clinic are important priorities to avoid viral transmission. The difficulty in PCR negative patients was the confusing effect of burns as most of the laboratory and radiologic findings overlaps with the major burns' consequences. Findings, cannot be explained by the clinical course of burn, should indicate COVID infection. Regarding our results, burn patient treatment routines can be applied safely by competence to focused and re-adopted precautions as there were no hospital acquired COVID-19. Patients must trained for cross-contamination. Healthcare's must prioritize their own health under all situations including pandemics. Updating, the preventive cautions and rigid compliance are a must.
\end{abstract}

Keywords: Burns; coronavirus disease; inpatient; pandemic.

\section{INTRODUCTION}

Coronavirus disease (COVID-19), which is wide-spread and high contagious viral pneumonia accepted as a pandemic by the World Health Organization at January 2020. In Turkey, after diagnosing the first case on March II, nationwide lockdowns have started at the mid-March.

From the beginning of 2020, the pandemic has also affected our practice as healthcare professionals. Especially the treatment and management of burn patients during pandemic has serious risks. ${ }^{[1]}$ Burn cases are considered as emergency cases and postpones or delayed treatment can cause several morbidities. As burn surgeons, our goal should be to provide safe care to our patients; however, ensuring the safety of the whole team giving burn care at burn centers is also a must.

The burn patients are usually debilitated and require a prolonged hospital stay and multiple operative procedures which put patients and the burn team involved in their care at in-

Cite this article as: Akın M, Akgün AE, Birben B, Akın T, Yastı AÇ. Management of burns during coronavirus disease pandemic: Single center experience and outcomes. Ulus Travma Acil Cerrahi Derg 2021;27:677-683.

Address for correspondence: Merve Akın, M.D.

Ankara Şehir Hastanesi, Genel Cerrahi Kliniği, Ankara, Turkey

Tel: +90 312 - 5526000 E-mail: merveakin.2002@gmail.com

Ulus Travma Acil Cerrahi Derg 2021;27(6):677-683 DOI: 10.14744/tjtes.202I.77088 Submitted: 06.05.202I Accepted: 01.07.202I

Copyright 2021 Turkish Association of Trauma and Emergency Surgery 
creased risk of coronavirus infections and transmission. This warrants special caution to the burn team while managing such patients. ${ }^{[2]}$

Our burn center, with six burn intensive care unit (ICU), 18 ward beds, two operating theatres and four dressing change rooms, is a referral center in Turkey and accept patients countrywide and also abroad referrals. After the pandemic, some of the ICU and ward beds, one operating theatre and one dressing change room of our center were reserved for COVID- 19 positive burn patients.

We would like to share our own experience during the pandemic in hospitalized burn patients with COVID-19 infection with the literature.

\section{MATERIALS AND METHODS}

The records of the patients who were hospitalized in our Burn Treatment Center (BTC) between April I, 2020, and December 31, 2020, were retrospectively obtained from the hos- pital information system. Burn patients who have confirmed COVID-19 infection with either polymerase chain reaction (PCR) or computed tomography (CT) imaging and laboratory findings (CBC, Ferritin, D-Dimer, Procalcitonin, and CRP), and approved by the infection control committee of the hospital were included to the study. Age, gender, total body surface area (TBSA), number and sort of operations performed, ICU stay, ward stay, total length of stay (LOS), morbidity, and mortality were analyzed. Furthermore, medical staff meticulously observed for any kind of symptom that can be considered as COVID-19 infection. According to the advices of infection control committee of the hospital, in the case of having any symptom of COVID infection, burn center staff got the PCR test. No routine screening tests were applied.

Our burn center is structured so that 6 burn ICU beds, 18 burn ward beds, two operating rooms (ORs), two burn bathrooms and four dressing change rooms including equipment for anesthesia, and policlinics just next to center. Burn center is located at the main building of the complex and is close to radiology and main laboratories and is quite $100 \mathrm{~m} \mathrm{far}$

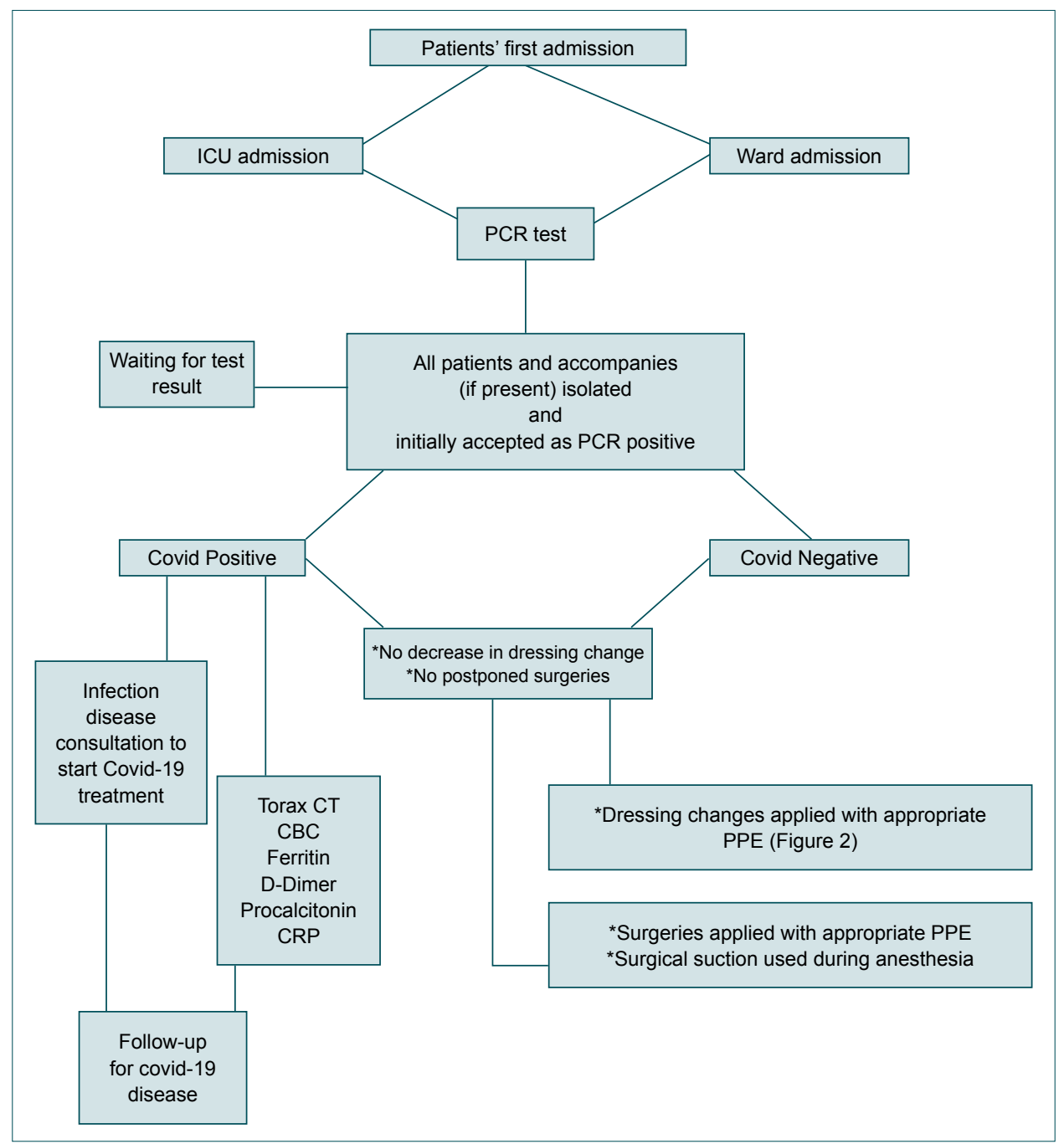

Figure 1. Management of burn patients during COVID-19 pandemic. 
from the nearest ward reserved for other medical disciplines. Briefly, all required parts of the burn are located in the burns center and is almost isolated from the rest of the hospital complex. None of the burn center staff has any extra job in the hospital including branch medical or administrative functions. And also, no temporary workers allowed to be in the burn clinic during the pandemic.

During the pandemic, a standard evaluation of patients performed for COVID-1 9 by adding an appendix to burn centers patient hospitalization protocol, according to the literature (Fig. I). Furthermore, two burn ICU beds, 4 burn ward beds, one operation room and one dressing room with shower and bath were reserved for the COVID-19 infected burn victims.

All patients had routine care for burn treatment as before pandemic. Dressing changes performed at least once a day, however, more than one dressing change was done where required. As early operative interventions are lifesaving precaution, none of the operation postponed because of COVID infection. Medical staff always used personal protective equipment (PPE) that recommended to use during aerosol generating procedures, ${ }^{[3]}$ during both dressing changes and operations including escharectomy, grafting, and hydrosurgery (Smith\&Nephew, Versajet $\left.\|^{\circledR}\right)$ although British Association of Plastic Reconstructive and Aesthetic Surgeons (BAPRAS) accepted hydrosurgery procedure as high-risk procedures regarding aerosolization. ${ }^{[4]}$

To prevent and/or minimize aerosolization, hospital central vacuum system integrated surgical suction aspiration was routinely used to aspirate the patients ventilated air during operations in the OR and at ICU to minimize the aerosol and viral load in the OR and ICU environment. ${ }^{[5]}$

Non-parametric Mann-Whitney $U$ test was used to compare means and Chi-square test to compare the groups, and $\mathrm{p}<0.05$ is accepted as scientifically significant. This retrospective observational study was approved by the local Institutional Review Board (E.Kurul-EI-20-I439/06/0I/202I).

\section{RESULTS}

Our BTC serving patients with 4 General Surgeons, 2 residents of Surgery, 19 Nurses, 2 physiotherapists, and other assistant staff with a total number of thirty-five.

During the pandemic, II burn patients hospitalized to our clinic with the diagnosis of concomitant Covid-19 infection. The mean age of the patients was $5 \mathrm{I}( \pm 19.37)$ years old. There were nine (81.8\%) male and two females (18.2\%). The mean burned TBSA was $34.36 \%([ \pm 21.97 \%]$; range $1 \%-64 \%)$ and deep dermal burns composed $14.36 \%( \pm 9.5 \%)$ of the burn wounds.

While mean burn ICU stay was $19.73( \pm 19.36)$ days for the victims, ward stay and total LOS were $17.18( \pm 16.73)$ and $36.9 \mathrm{I}( \pm 20.46)$ days, respectively (Table I).

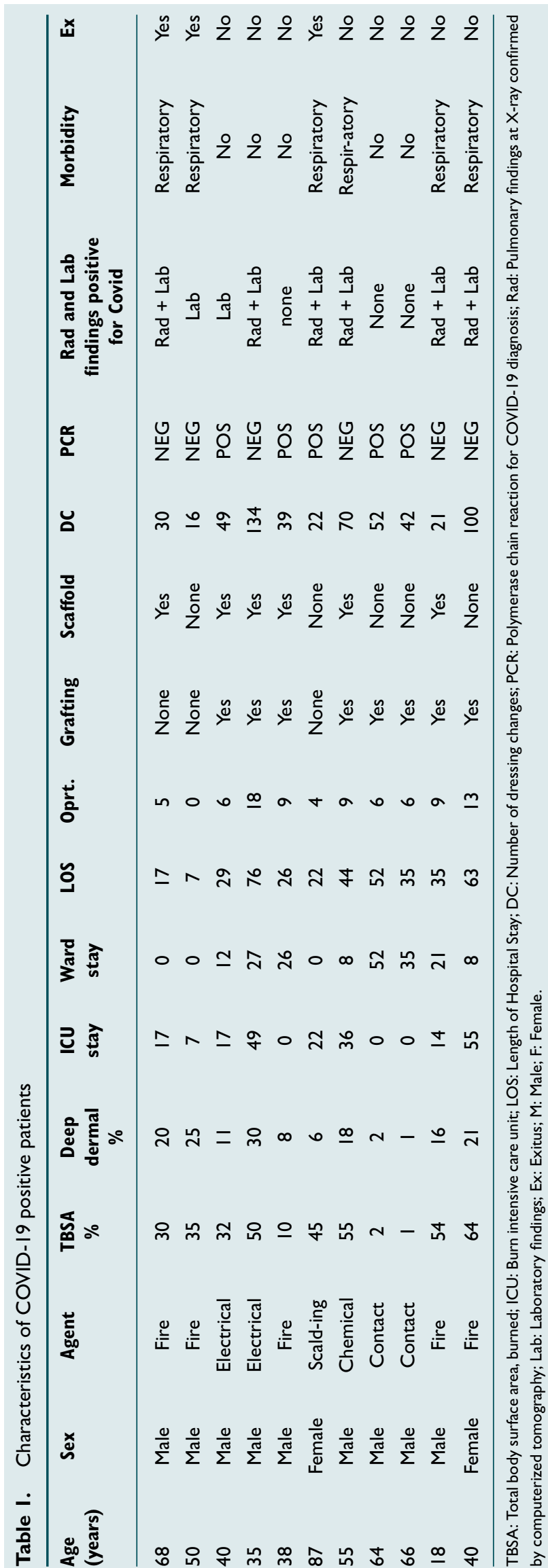


Table 2. Etiologies of the patients

\begin{tabular}{lcc}
\hline Etiology & Number & $\%$ \\
\hline Fire & 5 & 45.5 \\
Electrical & 2 & 18.2 \\
Scalding & 2 & 18.2 \\
Contact & 1 & 9.1 \\
Chemical & 1 & 9.1 \\
\hline
\end{tabular}

Table 3. Distribution of patients regarding polymerase chain reaction result and diagnosis

\begin{tabular}{lccc}
\hline & \multicolumn{2}{c}{ Polymerase chain reaction test } & Total \\
\cline { 2 - 3 } & Negative & Positive & \\
\hline Symptoms & & & \\
None & 0 & 3 & 3 \\
Laboratory findings & 1 & 1 & 2 \\
Radiological and & 5 & 1 & 6 \\
laboratory findings & & & \\
Total & 6 & 5 & 11 \\
\hline
\end{tabular}

Fire burns were the leading burn agent. All contact burns were diabetic patients and presented with foot burns. Etiologies are shown at Table 2.

Six (54.5\%) of the I I COVID- I9-infected patients were presented with negative PCR tests; however, symptoms, radiological, and laboratory findings supported the illness in eight patients including PCR negative ones (Table 3). Five of six PCR negative patients presented pulmonary complications. None of the patients presented with solely pulmonary findings. Only one patient presented with PCR positivity with laboratory and radiologic findings together. All COVID-19 patients received Favipiravir as anti-coronavirus therapy.

The patients underwent 85 operations and mean operation number was $7.7( \pm 4.7)$. One patient was died without surgery with deep second-degree burns, however, developed unexpected acute respiratory insufficiency that did not improved by mechanical respiratory support and died in $10 \mathrm{~h}$. Eight patients had split-thickness skin grafting procedures some requiring expansion of grafts through mesher mostly at I:3 scale. Scaffold applications were done to six patients.

Of the 85 operations in OR, hydrosurgery (Smith\&Nephew, Versajet $\|^{\circledR}$ ) applied in four patients at seven operations. During their stay, 475 dressing changes were done to the patients with mean $52.27( \pm 36.42)$ dressing changes. All preventive measurements were taken by both the surgical and ward team for the aerosolization of the procedure (Figs. 2 and 3).

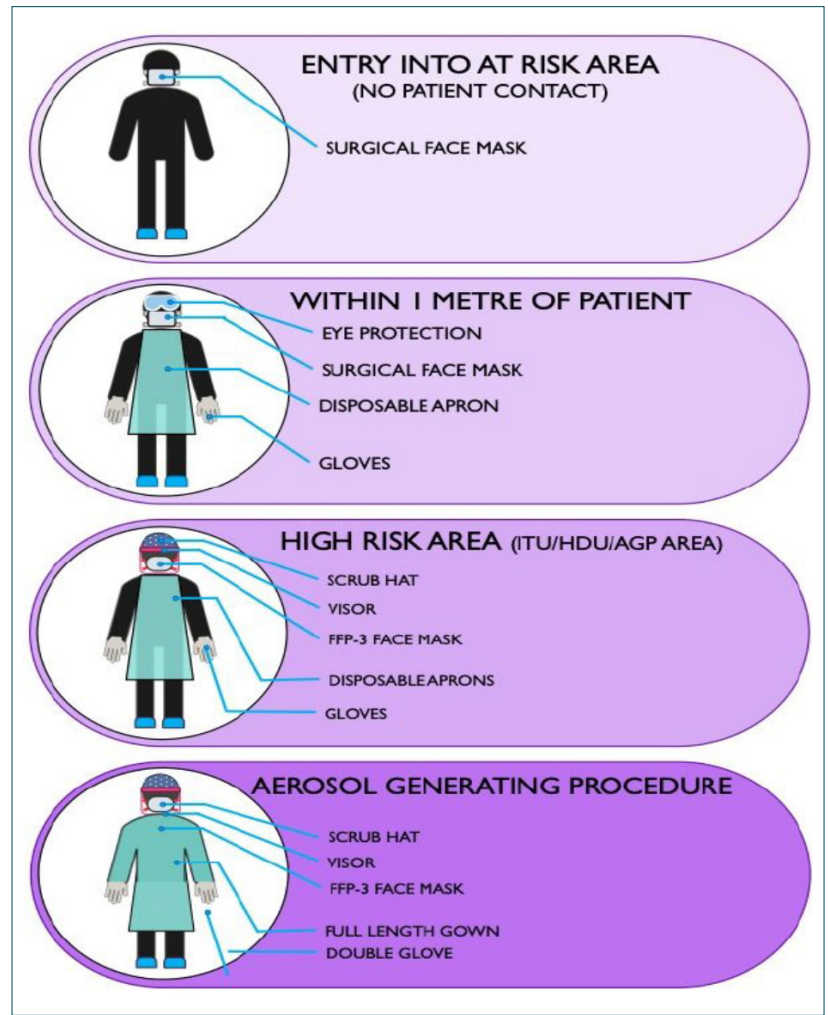

Figure 2. Personal protective equipment recommendations. ${ }^{[3]}$

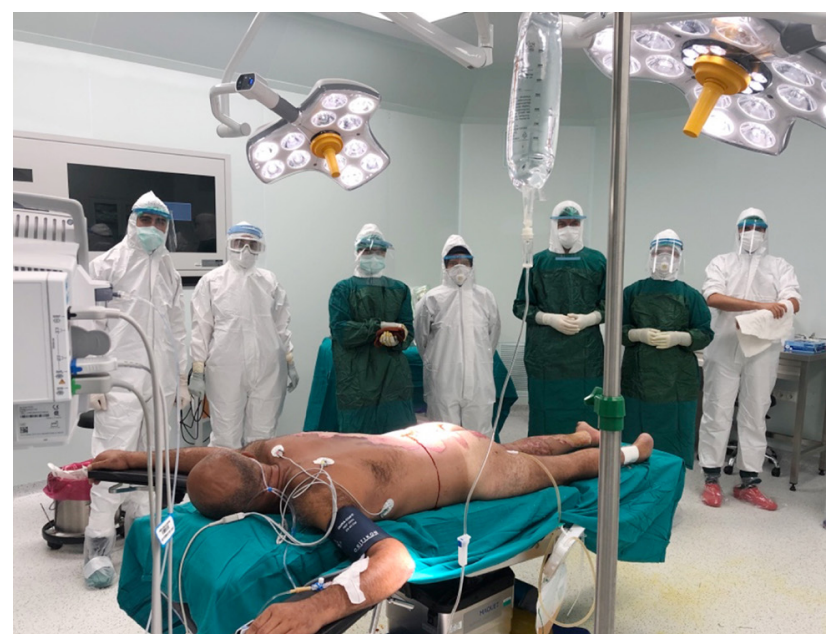

Figure 3. Preperation of operating team for covid-19 burn patient.

There were three mortalities (27.3\%). One mortality (50-year-old male with $35 \%$ fire burn) is described above. The $45 \%$ burned female at the age of 87 years developed massive aspiration of the gastric content and consequently died. A 68-year-old male was death due to respiratory failure. Comparison of patients regarding age, TBSA and deep dermal burn percent of the mortalities with the group showed no difference (Table 4). There was no sepsis among the mortalities and acute respiratory failure was the death cause at all.

All of II patients have diagnosis with PCR or isolated and accepted as positive for the $I^{\text {st }}$ week of their hospitalization. 
Table 4. Comparison of age, total body surface area and deep dermal burn percent of mortal and non-mortal patients

\begin{tabular}{lllll}
\hline & Mortality & $\mathbf{n}$ & Mean \pm Standard deviation & p \\
\hline Age & No & 8 & $44.50 \pm 16.160$ & 0.085 \\
& Yes & 3 & $68.33 \pm 18.502$ & \\
Total burned surface area & No & 8 & $33.50 \pm 25.879$ & 0.921 \\
& Yes & 3 & $36.67 \pm 7.638$ & \\
Deep dermal burn percent & No & 8 & $13.38 \pm 9.855$ & 0.630 \\
& Yes & 3 & $17.00 \pm 9.849$ &
\end{tabular}

None of the patients and their accompanies had COVID-19 infection during their treatment course at the hospital.

During the study period, none of the operating theatre staff had covid-19 infection. But two nurses and one general surgery resident had COVID- 19 infection and all received favipiravir as medical treatment and isolated at their homes for 2 weeks. End of the 2 weeks of non-complicated treatment course, all re-join to burn team and enrolled to works in burns department.

\section{DISCUSSION}

Burn centers are units that give medical care to serious patients with large burn wounds. Hospitalization criteria do not and cannot consider COVID-19 or another disease existence. During the pandemic period, it is necessary to continue healthcare service by protecting both patients and the health-care team.

After wide spreading COVID-19 infection accepted as a pandemic, for both control of transmission and protection of the healthcare givers, most of the medical science associations published guidelines and recommendations. ${ }^{[2-4,6]}$

They all mentioned the importance of team training about safety and prevention. ${ }^{[2]}$ In our hospital from the beginning of the pandemic every single health staff, patients and their accompanies (care-givers) trained about the COVID- 19 infection, transmission ways, prevention, use of PPEs, and also the symptoms of infection. The absence of in-hospital acquired COVID-19 infection in our burn center, including the patients and their care-givers, was the reflection of these strict precautions and meticulous control of the compliance.

Li et al. ${ }^{[7]}$ suggested strengthened access control of their clinic. In our center, caregivers in the ward were not allowed to accompany patients unless they need any special assistance while using their hands or walking. Visitors from outside were not also allowed to enter into the ward and the caregivers couldn't leave the ward. In case those caregivers should go out from their rooms, firstly the security and the nurses informed, and they have informed to perform hand hygiene and face hygiene when they come back to their room.

The importance of ambulation for burn victims is well known. In our Burn center during Covid-19 pandemic, a time schedule was created for patients for ambulation. Thus, it was ensured that there was not more than one patient in the ambulation area at the same time. It also adds to the preventive measurements aimed to interrupt infection transmission among the clinic if any.

Most of the burn centers and guidelines that shared their COVID-19 experience recommend both reducing the dressing frequency and postponing operations unless there is an emergency to reduce patient contact as much as possible. ${ }^{[7,8]}$ Nevertheless, those recommendations we keep our routine treatment regimen just taking strict COVID-19 precautions and up to date only 2 of our nurses and one resident diagnosed by COVID-19 infection. They did not have contact with any of the patients after the disease is suspected, and the source of the infection is approved by filiation team as out of hospital. A total of 475 dressing changing were applied to the patients during the study period. Against the suggestions of Juan and $\mathrm{Li}$, our results showed that dressing changes are not necessarily postponed as the team takes all the required precautions to prevent viral transmission.

All the medical staff inside the OR strictly implement standard protective measures and hand hygiene as per the CDC guidelines for airborne and droplet infections. ${ }^{[2]}$ In an actively infected patient, all measures have taken to reduce liquid splash and contamination. During the pandemic, at our center, to minimize the surgery time, every dressing tool kept ready in the OR before the transfer of patient to OR. Furthermore, appropriate devices such as staples were used for fixation instead of suturing. Several studies have found that the viral load remains in essentially all body fluids and surgical smoke from electrocautery. Thus, the generation of smoke minimized by reducing the usage of monopolar cautery and surgical suction has used to aspirate the smoke. ${ }^{[2]}$ During 
the study, 85 operations including grefting and hydrodurgery were done in the $O R$ and there was no viral transmission both the surgical and anesthesiology team. Hospital central vacuum system was strictly used to remove the patients' expired breath from the room during the perioperative period. [5] All the operations were done by the senior surgeons and even our hospital is an educational center, training and education ignored at the COVID-19 infected patients to lessen the operative time.

Severe acute respiratory syndrome coronavirus 2 (SARS) is found to survive on the surfaces of operating theaters for up to 9 days and also runs the risk of contaminating other ORs. ${ }^{[2]}$ It is also well known that COVID-19 is a heavy virus that falls down in about two meters distance even talking face to face. It is the reason for keeping the social distance to bloc airborne transmission. It recognized us to take an extra precaution at the OR. At our center one of those ORs reserved for COVID-19 positive patients. During COVID-19 period, after the last case, we left the OR without cleaning and let particles to fall down until next morning to enhance the safety of cleaning staff from airborne transmission either. Furthermore, in our clinic, all patient rooms including ward and ICU and two of four dressing rooms with shower and bath are negative-pressured too, which also blocs the air-spread of virus in the clinic.

Regarding burn victims with COVID-19 infection, laboratory and radiological findings can be confusional that both inflammatory mediators and radiological images of covid-19 infection and burn metabolism are similar. We observed that five of the eleven patients were PCR positive and remaining 6 were PCR negative. Among those PCR negative patients, there were no symptoms like fever, cough or dyspnea reminiscent of COVID infection. However, laboratory findings and radiologic investigations revealed COVID disease. Five of these 6 PCR negative patients had pulmonary complications at the following days. On the other site, of the patients with pulmonary complications, there was $50 \%$ mortality reflecting the importance of pulmonary functions at the clinical outcome of the disease. Patients with laboratory and radiological findings that cannot be explained by the clinical course of burn should alert for COVID infection and further examinations should be taken into consideration.

There were no difference regarding age, burned TBSA and deep dermal burned area percentage between the mortal and non-mortal cases. Sepsis and consequently developed multi organ failure is the main death reason at the major burn patients. However, at our all mortalities (three), death reason was respiratory failure (one due to massive gastric content aspiration) and none of them developed sepsis. To our opinion, COVID- 19 related pulmonary insufficiency was the main death cause in these patients, which is different and more quickly than the classical pattern that we usually see as multi organ failure following sepsis.
During the pandemic, we have limited the work hours of doctors and nurses. Operating theater staff left the hospital as operations were finished. Furthermore, we shifted the checkin and check-out hours out of rush-hours to keep our clinic staff away from the public crowd. We highly recommended not to use public transportation if possible. Burn center staff was not allowed to be assigned any extra job in the hospital and no temporary ones allowed to be in the burn clinic. Our clinic has its private food-court in the clinic for only burn staff to serve food at the breakfast, lunch and dinner. Not more than eight people allowed to sit in the court at the same time to keep two meters of social distance and one our dinning time was elongated to $2 \mathrm{~h}$ to lessen the time squeeze. It also diminished the possibility of airborne virus transmission during dinning.

Implementation of and competence to preventive strategies have prevented COVID-19 infection among the doctors, nurses and other health staff in our department. Competence to our measures to minimize the contact of individuals with each other, there was no contamination not only in our team but also in the patients and their relatives.

The limitations of this study include the small patient population and the retrospective nature of study.

\section{Conclusion}

SARS in 2003; H5NI (Bird flu) in 2005; HINI (swine flu) in 2009 occurred world-wide. And finally, SARS- COV-19 is responsible for the most severe pandemic that affect all over the world. Those epidemics and pandemics taught us the importance of health systems as well as easier access to healthcare facilitates the spread of infection. With this view, health-care staff should be alert and prioritize their own health in the transmission of infection in today's shrinking global world.

Like all emergencies, delay in the treatment of burn victims unfortunately results in mortality that we should keep giving the same quality of care by taking all necessary high level preventing measures.

Ethics Committee Approval: This study was approved by the Ankara City Hospital Ethics Committee (Date: 06.01.2021, Decision No: El-20-1439).

Peer-review: Internally peer-reviewed.

Authorship Contributions: Concept: M.A., A.Ç.Y.; Design: M.A., A.E.A.; Supervision: T.A., B.B.; Data: M.A., A.E.A.; Analysis: A.Ç.Y., M.A.; Literature search: M.A., T.A.; Writing: M.A., A.E.A., A.Ç.Y.; Critical revision: A.Ç.Y.

Conflict of Interest: None declared.

Financial Disclosure: The authors declared that this study has received no financial support. 


\section{REFERENCES}

1. Ma S, Yuan Z, Peng Y, Chen J, Li H, Luo Q, et al. Experience and suggestion of medical practices for burns during the outbreak of COVID-19. Burns 2020;46:749-55. [CrossRef]

2. Saha S, Kumar A, Dash S, Singhal M. Managing burns during COVID-19 outbreak. J Burn Care Res 2020;41:1033-6. [CrossRef]

3. Jessop ZM, Dobbs TD, Ali SR, Combellack E, Clancy R, Ibrahim N, et al. Personal protective equipment for surgeons during COVID-19 pandemic: Systematic review of availability, usage and rationing. Br J Surg 2020;107:1262-80. [CrossRef]

4. Brithish Association of Plastic and Reconstructive and Aesthetic Surgeons (BAPRAS), Covid-19 Advice for Members, BAPRAS PPE Guidance for Plastic Surgeons. Available from: http://www.bapras.org.uk/ docs/default-source/covid-19-docs/ppe-guidance-for-plastic-surgeons-- -bapras-branding.pdf?:sfursn=2. Accesed 28 Dec, 2020.

5. Akin M, Tuncer HB, Yasti AC. Using surgical suction suring sedation to minimize the spread of aerosols. Burns 2021;47:979-81. [CrossRef]

6. World Health Organization. Rational use of Personal Protective Equipment for Coronavirus Disease 2019 (COVID-19). Geneva: World Health Organization; 2020. p. 1-7. Available from: https://apps.who. int/iris/bitstream/handle/10665/331215/WHO-2019-nCov-IPCPPE_use-2020.1-eng.pdf. Accessed 23 Apr, 2020.

7. Li N, Liu T, Chen H, Liao J, Li H, Luo Q, et al. Management strategies for the burn ward during COVID-19 pandemic. Burns 2020;46:75661. [CrossRef]

8. Barret JP, Chong SJ, Depetris N, Fisher MD, Luo G, Moiemen N, et al. Burn center function during the COVID-19 pandemic: An international multi-center report of strategy and experience. Burns 2020;46:1021-35. [CrossRef]

\section{ORIJINAL ÇALIŞMA - ÖZET}

\section{Covid-19 pandemi sürecinde yanıkların yönetimi: Tek merkezin sonuçları ve deneyimi Dr. Merve Akın, ${ }^{1}$ Dr. Ali Emre Akgün, ${ }^{1}$ Dr. Birkan Birben, ${ }^{1}$ Dr. Tezcan Akın, ${ }^{1}$ Dr. Ahmet Çınar Yastı ${ }^{2}$}

\section{${ }^{1}$ Ankara Şehir Hastanesi, Genel Cerrahi Kliniği, Ankara}

${ }^{2}$ Sağıık Bilimleri Üniversitesi Tıp Fakültesi, Genel Cerrahi Anabilim Dalı, İstanbul

AMAÇ: Yanık hastalarında uzun süreli hastanede yatış ve tekrarlayan ameliyatlar bulaş riskini artırmaktadır. Covid- 19 enfeksiyonu olan yatarak tedavi olan yanık hastaları hakkındaki deneyimimizi tartışıp paylaşmak istedik.

GEREÇ VE YÖNTEM: Covid-19 enfeksiyonu teyit edilmiş, hastanede yatan yanık hastaları çalışmaya alındı. Yaş, cinsiyet, toplam vücut yanık yüzey alanı (TVYA), ameliyat sayısı, yapılan ameliyat, pansuman sayısı, yoğun bakım ve klinikte kalıs süresi, mortalite ve morbidite analiz edildi. Pandemi süresince sağlık personeli olası covid enfeksiyonu açısından takip edildi.

BULGULAR: Covid-19 enfeksiyonu olan II hastanın yaş ortalaması 5 I ( \pm |9.37), yanık TVYA ise \%34.36 ( $\pm 21.97 \%)$ idi. Altı hastada (\%54.5) Covid-19 PCR testi negatif olmasına rağmen semptom ve bulgular Covid-19 enfeksiyonu ile uyumluydu. Hastalara hidrocerrahi de dahil olmak üzere toplam 85 ameliyat yapıldı. Toplam 475 pansuman yapıldı. Üç hasta sepsise bağıı olmayan respiratuvar yetersizlik nedeni ile hayatını kaybetti. Yaş, TVYA ve yanık derinlikleri arasında bir fark tespit edilmedi. Yanık tedavi merkezinde yatan diğer hastalarda ve sağlık personelinde bu süreçte hastane kaynaklı Covid-19 enfeksiyonu tespit edilmedi.

TARTıŞMA: Pandemiler sırasında sağıık hizmeti devam etmek zorundadır. Farkındalık, kişisel koruyucu ekipmanların uygun kullanımı, sosyal mesafe, kliniğe kontrollü erişimin sağlanması viral bulaşı engellemede önde gelen yöntemlerdir. Covid-19 PCR negatif olan hastalarda Covid-19 enfeksiyon tanısı koymak zordur. Majör yanıklı hastalarda ise her iki durumun bulgularının benzer olması tanıyı koymayı daha da zorlaştııı. Hastanın kliniği yanık kliniği ile açıklanamıyorsa Covid- 19 akılda bulundurulmalıdır. Sonuçlarımız dikkate alındığında ve kliniğimizde hastane kaynaklı viral bulaş olmadığı da göz önüne alındığında yanık hastalarının rutin tedavi şemalarının revize edilen önlemler eşliğinde güvenle yapılabileceği aşikardır. Klinikte yatan hasta ve yakınlarının da viral bulaş açısından bilgilendirilmeleri önemlidir. Sağık çalışanları pandemiler de dahil olmak üzere her durumda kendi sağıklarını en önde tutmalıdırlar. Alınması gereken tedbir ve önlemleri sürekli güncel tutmak ve mutlak uyum şarttır.

Anahtar sözcükler: Covid-19; pandemi; yanık; yatan hasta.

Ulus Travma Acil Cerrahi Derg 2021;27(6):677-683 doi: 10.14744/tjtes.2021.77088 